
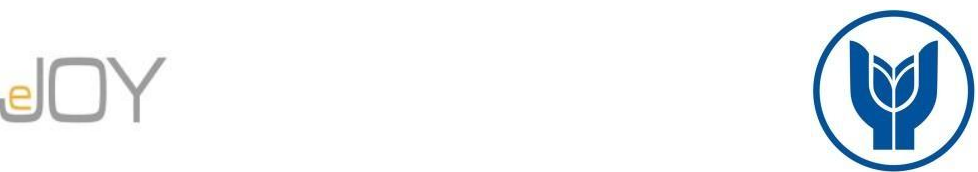

Taş, A., Özkara, Z. U., Aydıntan, B. / Journal of Yasar University, 2021, 16/61, 147-169

\title{
Yönetici Desteğinin Ona Duyulan Duygusal Güven Üzerindeki Etkisi: Bilișsel Güvenin Aracılık Rolü ${ }^{1}$
}

\section{The Effect of Supervisor Support on Affect-Based Trust in Him/Her: The Mediating Role of Coginition-Based Trust}

\author{
Aynur TAŞ, Hakkari Üniversitesi, Türkiye, aynurtas@ hakkari.edu.tr \\ Orcid No: 0000-0001-6810-8358
}

Zülfi Umut ÖZKARA, Ankara Hacı Bayram Veli Üniversitesi, Türkiye, umut.ozkara@hbv.edu.tr

Orcid No: 0000-0002-5031-808X

Belgin AYDINTAN, Ankara Hacı Bayram Veli Üniversitesi, Türkiye, belgin.aydintan@hbv.edu.tr

Orcid No: 0000-0002-9057-4336

\begin{abstract}
Öz: Çalı̧̧ma çerçevesinde; algllanan yönetici desteğiyle çalışanların bir üst yöneticilerine duydukları duygusal güven arasındaki iliş̧kide çalışanların bu yöneticilerine duydukları bilişsel güvenin aractllk etkisi araşttrılmıştır. Araştırmanın veri seti; Türkiye'nin doğusundaki bir devlet üniversitesinde görev yapmakta olan 109'u akademik ve 101 'i idari çallşanlardan toplanan 210 anketten meydana gelmektedir. Araştırmanin veri girişi için SPSS 24 programı kullanılmıştır. Elde edilen veriler, SPSS 24 ve AMOS 24 programlarıly analiz edilmiştir. Bu çalışmada; "bütün bir yapıda doğrulayıcı faktör", "iç tutarlılık (Cronbach Alpha)", "Pearson korelasyon", "birincilikinci yapısal eşitlik modellemesi" ve interaktif ortamda "Sobel testi" analizleri yapılmuştır. Çalışmaya katılanlar bakımından analiz sonuçlarına göre; algılanan yönetici desteği çalı̧̧anların bir üst yöneticilerine duydukları bilişsel güveni, bilişsel güven de çalı̧̧anların bu yöneticilerine duydukları duygusal güveni anlamlı ve pozitif bir şekilde doğrudan etkilemektedir. Ayrıca algılanan yönetici desteği çalışanların bir üst yöneticilerine duyduklarl duygusal güveni hem doğrudan hem de bilişsel güven üzerinden dolaylı olarak anlamlı ve pozitif bir şekilde etkilemektedir. O halde; çalıșma kapsamında kurulan mekanizmada, bilişsel güven kısmi aracılık rolüne sahiptir. Bu çalışmada; algllanan yönetici desteği düzeyindeki artışın yöneticiye duyulan bilişsel ve duygusal güven düzeyleri üzerindeki yükseltici etkileri yoluyla güvenin örgüt üzerindeki olumlu etkilerini arttırmanın ve böylece örgüte katkı sağlamanın mümkün olduğu sonucuna ulaşılmaktadır.
\end{abstract}

Anahtar Sözcükler: Algılanan Yönetici Desteği, Bilişsel Güven, Duygusal Güven, Sosyal Değişim Kuramı

JEL Sinıflandirmast: M54, M12, D23, O15

Abstract: This study has investigated the mediating effect of employees' cognition-based trust in their immediate supervisors in the relationship between perceived supervisor support and employees' affect-based trust in these supervisors. Dataset of the study consists of total 210 questionnaires gathered from 109 academic and 101 administrative staff at a state university in eastern Turkey. Data input of the research has been done with SPSS 24 software, and afterwards data obtained has been analyzed through SPSS 24 and AMOS 24 softwares. "Overall confirmatory factor", "internal consistency (Cronbach Alpha)", "Pearson correlation", "first/second structural equation modeling" and "Sobel test" analyzes in interactive environment have been performed in this study. According to the analysis results in terms of participants in this study, perceived supervisor support directly affects employees' cognition-based trust in their immediate supervisors in a significant and positive way. And then, cognition-based trust has a direct, significant and positive effect on employees' affect-based trust in these supervisors. In addition, perceived supervisor support affects employees' affect-based trust in their immediate supervisors both directly and indirectly through the cognition-based trust in a significant and positive

\footnotetext{
${ }^{1}$ Bu çalışma; 01-02 Kasım 2019 tarihlerinde Burdur'da gerçekleştirilen 7. Örgütsel Davranış Kongresi’nde sözlü bildiri olarak sunulan çalışmanın genişletilmiş halidir.
}

Makale Gecmiși / Article History

Başvuru Tarihi / Date of Application Kabul Tarihi / Acceptance Date
: 11 Ağustos / August 2020

: 18 Kasım / November 2020 
way. Therefore, cognition-based trust has a partial mediating role in the mechanism established within the scope of the study. In this study, it is concluded that it is possible to increase the benefit of trust to the organization and thus to contribute to the organization through the enhancing effects of an increment in the level of perceived supervisor support on the levels of cognition-and affect-based trust in supervisors.

Keywords: Perceived Supervisor Support, Cognition-based Trust, Affect-based Trust, Social Exchange Theory

JEL Classification: M54, M12, D23, O15

\section{Giriş}

Çalışmanın temel amacı çerçevesinde; algılanan yönetici desteğinin, çalışanların bir üst yöneticilerine duydukları duygusal güven üzerindeki etkisi araştırılarak bu ilişkide çalışanların bu yöneticilerine duydukları bilişsel güvenin üstlendiği aracılık rolü sinanmaktadir.

Alanyazında; algılanan yönetici desteğiyle yöneticiye duyulan güven arasındaki ilişkinin araştırıldığı ampirik çalışmalar (Abuelhassan vd., 2018; Akram vd, 2018; Chen vd., 2008; DeConinck, 2010; Holland vd., 2017; Ji ve Jan, 2020; Keskinkılıç Kara vd., 2015; Lewicka vd., 2018; Neves ve Caetano, 2006; Stinglhamber vd., 2006; Taş vd., 2019; Yakut Özek, 2016) tespit edilmiştir. Ayrıca literatürde bilişsel güven ile duygusal güven arasındaki ilişkinin araştırıldığı çok sayıda çalışma (Ergeneli vd., 2007; Lu, 2014; McAllister, 1995; Newman vd., 2014; Özkara ve Sağlam Arı, 2019; Özkara, 2019; Sağlam Arı ve Tunçay, 2010; Sağlam Arı, 2003b; Schaubroeck vd., 2011; Taş vd., 2019; Tunçay, 2009; Zhu ve Akhtar, 2014a; Zhu ve Akhtar, 2014b) da bulunmaktadır. Bununla birlikte, algılanan yönetici desteğiyle yöneticiye duyulan güven arasındaki ilişkinin araştırıldığg alanyazındaki görgül çalışmalarda; Taş ve diğerlerinin (2019) çalışması haricinde yöneticiye duyulan güven bilişsel ve duygusal temelde ele alınmamıştır. Bu çalışmada; Taş ve diğerlerinin (2019) çalışmasında olduğu gibi yöneticiye duyulan güven duygusal ve bilişsel temelde birbiriyle toplanamayan iki farklı yapı şeklinde incelenmektedir.

Alanyazında; hem algılanan yönetici desteği hem de bilişsel ve duygusal güven bireye, gruba ve örgüte fayda sağlayan faktörler olarak görülmektedir. Çalışma kapsamında; “algılanan yönetici desteği düzeyindeki artışın çalışanların bir üst yöneticilerine duydukları bilişsel güven düzeyi üzerindeki yükseltici etkisi ve ayrıca hem algılanan yönetici desteği hem de bilişsel güven düzeylerindeki artışın çalışanların bu yöneticilerine duydukları duygusal güven düzeyi üzerindeki yükseltici etkileri yoluyla örgüte katkı sağlamak mümkün müdür?” sorusuna cevap aranmaktadır.

$\mathrm{Bu}$ araştırma kapsamında; yönetici desteğiyle yöneticiye duyulan güven arasındaki ilişkilerin incelendiği dikkate alındığında, çalışmanın Karşılıklılık Normu'nu (The Norm of Reciprocity- Gouldner, 1960) esas alan Sosyal Değişim Kuramı'na (Social Exchange Theory- 
Blau, 1964) dayandığ1 söylenebilir. Setton ve diğerlerine (1996) göre; yönetici ile ast arasındaki olumlu ve faydalı eylemler bu iki taraf arasındaki değiş-tokuş ilişsisinin yükssek kalitede oluşmasını sağlamaktadır. Sosyal Değişim Kuramı'ndan hareketle çalışma çerçevesinde; çalışanların amirlerinden maddi, duygusal ve bilgisel anlamda destek aldıklarına dair algılarının yükselmesi durumunda, astların hem amirlerinin işinin ehli ve disiplinli olduğuna dair inançlarının hem de işte ve iş dışında amirleri tarafından önemseneceklerine ve herhangi bir zorlukla karşılaştıklarında amirlerinden yardım alacaklarına dair inançlarının artması beklenmektedir.

Çalışmanın bundan sonraki kısmında; araştırma modelinin kurulması ve hipotezinin geliştirilmesi için araştırmanın amacı ekseninde yönetici desteği yanında onu da içine alan örgütsel destek konusu ve yöneticiye duyulan güven ile birlikte onu da kapsayan güven konusu teorik bilgiler ışığında açıklanmaktadır. Ayrıca örgütsel davranış alanı bağlamında destek ve güven değişkenleri arasındaki ilişkilerin incelendiği ampirik çalışmalara yer verilmektedir.

\section{Literatür Taraması}

\subsection{Algılanan Örgütsel Destek ve Yönetici Desteği}

Algılanan örgütsel destek; örgütte hem çalışanların örgüte katkılarına değer verildiğine hem de onların rahatlığının, sağlığının ve mutluluğunun dikkate alındığına dair çalışanların inancını ifade etmektedir (Eisenberger vd., 1986: 500). Alanyazındaki görgül çalışmalara göre, örgütsel destek algıs1; örgütsel bağl1lığ1 (DeConinck ve Johnson, 2009; Gürbüz, 2012; Rahmani ve Heydari, 2017), işten tatmini (Akkoç vd., 2012; Sarıkaya, 2019), örgütten tatmini (Paille vd., 2010), örgütsel özdeşleşmeyi (Afacan Fındıklı, 2014), örgütsel vatandaşlık davranışlarını (Asgari vd., 2008; Paille vd., 2010) arttırırken, örgütsel sessizliği (Singh ve Malhotra, 2015) ve işten ayrılma niyetini (Afacan Fındıklı, 2014) azaltır. Bu çalışmalardan hareketle örgütsel destek algısının örgüte katkı sağlayan bir faktör olduğu dikkate alındığında, örgütsel desteğin öncülleri örgütlerde önem kazanmaktadır. Literatürdeki ampirik çalışmalara göre; lider-üye etkileşiminin kalitesi (Asgari vd., 2008) ve işlemsel adalet (DeConinck ve Johnson, 2009) gibi değişkenlerin yanı sıra algılanan yönetici desteği de örgütsel desteğin öncülleri arasındadır. Algılanan örgütsel destek, yönetici desteğiyle anlamlı ve olumlu yönde bir ilişkiye sahiptir (örn.: Afacan Fındıklı, 2014; DeConinck ve Johnson, 2009; DeConinck, 2010; Keskinkılıç Kara vd., 2015; Stinglhamber vd., 2006). Ayrıca algılanan yönetici desteği örgütsel desteğin olumlu bir yordayıcısıdır (örn.: DeConinck ve Johnson, 2009; DeConinck, 2010). 
İş görenlerin çalıştığı örgütten aldığı desteğe dair algisı "algılanan örgütsel destek", yöneticisinden aldığı desteğe dair algısı ise "algılanan yönetici desteği" şeklinde isimlendirilmektedir (Akın, 2008: 143). Bhanthumnavin (2000: 160), algılanan yönetici desteğini; "çalı̧̧anların yöneticilerinden duygusal, bilgisel ve maddi anlamda destek aldıklarına dair bir algı" olarak açıklamaktadır. Duygusal anlamda yönetici desteği; yöneticilerin çalışanlarına hem sözlü hem de sözlü olmayan (örn.: el sıkışma, sarılma ve kucaklama gibi) biçimde ilgi ve sevgi göstermesini, değer vermesini, saygı duymasını, çalşsanlarının iş ortamında karşılaştıkları stres ve çatı̧̧a gibi zorlukların üstesinden gelebilmeleri için onlara gerekli yardımları yapmasını, bilgisel anlamda yönetici desteği; yöneticinin işe ilişkin bilgi ve becerileri işığında çalışanlarının verimliliğini arttırmak amacıyla uyguladığı ödül, ceza, geri bildirim ve rehberlik etme davranışlarını, maddi anlamda yönetici desteği ise yöneticilerin çalışanlarına zaman ayırmalarını ve onlar için yaptıkları mal, teçhizat ve finansal yardımları kapsamaktadır (Bhanthumnavin, 2000). Algılanan yönetici desteği; "çalı̧̧anların bir üst amirleri tarafindan gördükleri desteğe dair algısl" olarak ele alınabilir (Yoon ve Lim, 1999: 925). Bu çalışma çerçevesinde; yönetici desteği bu bakış açısından hareketle incelenmektedir.

Amirler astlarına ihtiyaçları doğrultusunda destek vererek, aslında örgütsel amaçlara ulaşmakta astların sunacağı katkıyı yükseltmeyi arzu ederler (Taş ve Özkara, 2018: 511). Tablo 1'de görülen literatürdeki ampirik çalışmalara göre; lider-üye etkilişiminin kalitesi ve etkileşimsel adalet algılanan yönetici desteğinin öncülleridir. Yönetici desteği algısı yükseldiğinde; çalışanların sadakati güçlenir, iş performansı artar, çalışanlar örgütsel vatandaşlık davranışlarını ve yenilikçi davranışları daha fazla sergilerler, çalışanların örgütsel bağlllık ve özdeşleşme düzeyleri artar. Buna karşılık, çalışanların işten ayrılma niyeti ve iş stresi azalır.

Örgütsel davranış yazınında; "algılanan örgütsel destek ve yönetici desteği” ile ilişkilerinin incelendiği konulardan birisi de "güven"dir.

Tablo 1. Algılanan Yönetici Desteğinin Öncülleri ve Sonuçları

\begin{tabular}{|l|l|l|}
\hline Çalışmalar & $\begin{array}{l}\text { Değgişkenler } \\
\text { ve İlişkinin Yönü }\end{array}$ & Sonuçlar \\
\hline Chen vd., 2008 & LÜE $\rightarrow$ YD & (+) etki \\
\hline DeConinck ve Johnson, 2009; Stinglhamber vd., 2006 & EA $\rightarrow$ YD & $(+)$ etki \\
\hline Lewicka vd., 2018 & YD $\rightarrow$ S & $(+)$ etki \\
\hline DeConinck ve Johnson, 2009 & YD $\rightarrow$ İP & $(+)$ etki \\
\hline
\end{tabular}




\begin{tabular}{|l|l|l|}
\hline Chen vd., 2008 & YD $\rightarrow$ ÖVD & $(+)$ etki \\
\hline Abuelhassan vd., 2018 & YD $\rightarrow$ Ye.D & $(+)$ etki \\
\hline Aksoy, 2019 & YD $\rightarrow$ ÖB & $(+)$ etki \\
\hline Afacan Fındıklı, 2014 & YD $\rightarrow$ ÖÖ & $(+)$ etki \\
\hline $\begin{array}{l}\text { Afacan Fındıkl, 2014; Taş ve Özkara, 2018; } \\
\text { Taş ve Özkara, 2020 }\end{array}$ & YD $\rightarrow$ İAN & $(-)$ etki \\
\hline \begin{tabular}{l} 
Taş ve Özkara, 2018; Taş ve Özkara, 2020 \\
\hline
\end{tabular} & YD $\rightarrow$ İS & $(-)$ etki \\
\hline
\end{tabular}

Not: YD: Yönetici Desteği; LÜE: Lider-Üye Etkileşiminin Kalitesi; EA: Etkileşimsel Adalet; S: Sadakat; İP: İş Performansı; ÖVD: Örgütsel Vatandaşlık Davranışları; Ye.D: Yenilikçi Davranışlar; ÖB: Örgütsel Bağlılık; ÖÖ: Örgütsel Özdeşleşme; İAN: İşten Ayrılma Niyeti; İS: İş Stresi

\subsection{Güven ve Yöneticiye Duyulan Güven}

Literatürde; güven kavramına ilişkin çok sayıda tanım yer almaktadır, fakat üzerinde görüş birliğine varılmış tek bir tanım da bulunmamaktadır (Hosmer, 1995: 380-381). Bununla birlikte, güven kavramı en genel ifadeyle "bir tarafin karşı taraftan kişisel olarak yarar göreceğine veya en azından istismara ya da zarara uğramayacă̆ına yönelik olumlu beklenti içinde olma özelliği" ş̧eklinde tanımlanabilmektedir (Rousseau vd., 1998: 394). Psikoloji temelli bir kavram olan güven, disiplinler arası bir konudur. Sosyoloji, din, ekonomi ve işletme gibi farklı disiplinlerde geniş bir yelpazede incelenmiştir (Özen İşbaşı, 2000: 62); ancak bu çalışmada güven konusu işletme bilimi bakış açısıyla ele alınmaktadır.

İşletme biliminde temel olarak örgütlerde güven üzerinde durulmaktadır; çünkü örgütlerde güven, örgütler açısından hayati bir öneme sahiptir. Güven olmaksızın hiçbir örgüt hedefini gerçekleştiremez (Rosen, 1998). Örgütlerde güven; iç güven (örgütsel güven) ile dış güvenin toplamıdır. Dış güven; tedarikçilerin, ortakların, müşterilerin veya diğer paydaşların örgüte güveninden, iç güven yani örgütsel güven ise örgüt içindeki iklimden meydana gelmektedir (Huff ve Kelley, 2003: 85). Literatürdeki ampirik çalışmalara göre, örgütsel güven arttığında; örgütsel bağlılık (Aksoy, 2019; Rahmani ve Heydari, 2017) ve çalışanların iş tatmini (Sarıkaya, 2019) yükselmekte, örgütsel sessizlik (Singh ve Malhotra, 2015) ise azalmaktadır. $\mathrm{Bu}$ çalışmalardan hareketle örgütsel güvenin örgüte katkı sağlayan önemli bir unsur olduğu söylenebilir.

Örgütsel güven; örgüte (kuruma), yöneticiye ve iş (çalışma) arkadaşına güven temel boyutlarından oluşmaktadır (Uysal, 2019). Yöneticiye duyulan güven astlar tarafından örgütün bütününe atfedildiği için büyük önem taşımaktadır (Whitener vd., 1998: 516, 529). Alanyazındaki görgül çalışmalara göre; yöneticiye duyulan güven ile örgüte güven (Afacan Fındıklı vd., 2010; Eğriboyun, 2013; Gürbüz, 2012; Stinglhamber vd., 2006; Uysal, 2019) ve 
örgütsel güven (DeConinck, 2010; Eğriboyun, 2013; Gürbüz, 2012; Keskink1lıç Kara vd., 2015) arasında anlamlı ve olumlu yönde ikili ilişkiler bulunmaktadır.

İşletme biliminde güvenin araştırma alanları; bireyler arası güven, üst yönetime güven, örgütler arası güven ve müşterilerin işletmelere güveni şeklinde sınıflandırılabilir. Bireyler arası güven ise yöneticinin astına güveni, astın yöneticiye güveni, aynı düzeyde yer alan çalışanlar arası güven, departmanlar ve ekipler arası güven şeklinde toparlanabilir (Özkara ve Sağlam Arı, 2019: 18-19). Bu çalışma kapsamında; bireyler arası güven düzeyinde astın bir üst yöneticisine duyduğu güven incelenmektedir. McAllister (1995) güveni bireyler aras1 ilişkilerde bilişsel (bilgiye dayalı) ve duygusal (özdeşleşmeye dayalı) boyutta ele almıştır (McAllister, 1995). Bilişsel güven; bir bireyin yükümlülüklerini yerine getirmesi, teknik yetkinliği, güvenilirliği, bağlılı̆gı, doğruluğu ve dürüstlüğü hususlarında diğer bireylerin düşüncelerini içermektedir. Bilişsel güvene; doğruluk, adil olma, öngörülebilirlik ve geçmiş davranış kalıpları gibi kavramlar temel teşkil etmektedir. Bireyler; karşı tarafa güvenmek için ussal (akılc1) sebepler ararlar. Bilişsel güven; iş ortamı düşünülerek oluşturulur. İşlerin hatasız ve zamanında yapılması gibi ölçülebilir kriterlerden hareket edilir. Kişinin işinin ehli ve disiplinli olduğuna dair inancı ifade etmektedir. Duygusal güven; kişilere gösterilen ilgi ve özen neticesinde oluşan duygusal bağın yansıttığı özel ve kuvvetli bir ilişkiyi açıklamaktadır. Duygusal güvende ilişsinin kendisine içsel bir değer verilmekte ve karşı tarafın da aynı şekilde hissettiği düşünülmektedir. Duygusal güven; duygu, fikir ve beklentileri karş1lıklı olarak paylaşmayı, işteki sorunları dinlemeye istekli olmayı, güçlükler hakkında konuşabilmeyi, sorunlar karşısında ilgili ve yapıcı bir tavır sergilemeyi, ayrıca iş ilişkisine arkadaşlık hatta dostluk ilişkilerinin de katılmasını, bu doğrultuda geliştirilen duygusal ve özel bağların kuvvetli olmasını ifade etmektedir (Costigan vd., 1998: 304-309; McAllister, 1995: 25-33). McAllister (1995) çalışmasında; bilişsel ve duygusal güveni teorik açıdan birbirlerinden farklı yapılar olarak değerlendirmektedir. Bu değerlendirmeyi gerçekleştirdiği hem açımlayıcı hem de doğrulayıcı faktör analizleri ile istatistiksel olarak ispatlamaktadır. $\mathrm{Bu}$ durum; literatürdeki çoğu ampirik çalışmada (örn.: Lu, 2014; Newman vd., 2014; Özkara, 2019; Schaubroeck vd., 2011; Taş vd., 2019; Zhu ve Akhtar, 2014a; Zhu ve Akhtar, 2014b) istatistiksel olarak desteklenmiştir. O halde; bir bireyin duygusal temelde güvendiği bir kişiye bilişsel temelde güvenmeyebileceği ya da tam tersi bilişsel temelde güvendiği bir kişiye duygusal temelde güvenmeyebileceği söylenebilir.

Nienaber ve diğerlerinin (2015) gerçekleştirdikleri çalışmanın meta analiz sonuçlarına göre; yöneticinin, astın ve örgütün özellikleri astın yöneticisine duyduğu güvenin öncülleriyken, astın iş yerindeki davranışları, yöneticisine dair tutumu ve örgütsel seviyedeki 
etkiler astın yöneticisine duyduğu güvenin sonuçlarıdır. Tablo 2'de görülen alanyazındaki görgül çalışmalara göre; lider-üye etkileşiminin kalitesi, etkileşimsel ve yönetsel adalet, yöneticinin dürüstlüğü (integrity), becerisi (ability), yardımseverliği (benevolence), politik yetisi, etkileşimci, dönüşümcü ve otantik liderlik tarzları yanında astların güven eğilimi düzeyleri arttığında yöneticiye duyulan güven yükselmektedir. İstismarcı yönetim anlayışı ise yöneticiye duyulan güveni azaltmaktadır.

Çalışanlar ve yöneticileri arasında duyulan güven, sağlıklı bir çalışma ortamı için anahtar bir unsurdur (Wong ve Cummings, 2009). Tablo 2'de görülen literatürdeki çalışmalara göre, yöneticiye duyulan güven düzeyi arttıkça; örgütsel bağl1lık yanında astların yöneticiden ve işten tatmini yükselmekte, yöneticilerine bağlılıkları artmakta, astlar daha sadık olmakta, psikolojik olarak güçlenmekte, işlerine karşı daha fazla tutkunluk hissetmekte, örgütsel vatandaşlık ve yenilikçi davranışları daha çok sergilemekte, daha yüksek performans göstermektedir. Buna karşılık astların işten ayrılma niyeti, tükenmişliği ve duyarsızlığı ise azalmaktadir.

Tablo 3'te görülen alanyazındaki görgül çalışmalara göre; algılanan örgütsel destek ile örgütsel güven, örgüte güven, iş arkadaşına güven ve yöneticiye duyulan güven arasında ayrıca algılanan yönetici desteği ile örgütsel güven ve iş arkadaşına güven arasında anlamlı ve olumlu yönde ikili ilişkiler vardır. Bazı çalışmalara göre; örgütsel güven, örgüte güven, iş arkadaşına güven ve yöneticiye/yönetime duyulan güven algılanan örgütsel desteğin öncülleridir. Bazı çalışmalara göre ise algılanan yönetici desteği ve örgütsel destek örgütsel güvenin, algılanan örgütsel destek de örgüte güvenin öncülleridir. Ayrıca Afsar ve Saeed (2010)'un çalışmasında; algılanan örgütsel desteğin yöneticiye duyulan güvenin olumlu bir yordayıcısı olduğu önerilmektedir. Asgari ve diğerlerinin (2008) çalışmasına göre; algılanan örgütsel destek yöneticiye duyulan güveni yordamaktadır.

Örgütsel davranış alanı bağlamında destek ve güven konuları arasındaki bağlantıların ele alındığı bu çalışmanın buraya kadarki kısmında; algılanan örgütsel destek ile örgütsel güven, örgüte güven, iş arkadaşına güven ve yöneticiye/yönetime duyulan güven arasındaki ilişkiler yanında algılanan yönetici desteği ile örgütsel güven ve iş arkadaşına güven arasındaki ilişkiler anlatılmıştır. Çalışmanın bundan sonraki kısmında, araştırmanın temel amacı çerçevesinde; algılanan yönetici desteği ile yöneticiye duyulan güven arasındaki ilişkiler açıklanmaktadır.

Tablo 2. Yöneticiye Duyulan Güvenin Öncülleri ve Sonuçları

\begin{tabular}{|l|l|l|}
\hline Çalışmalar & Değişkenler & Sonuçlar \\
\hline
\end{tabular}




\begin{tabular}{|c|c|c|}
\hline & ve İlişkinin Yönü & \\
\hline Chen vd., 2008 & LÜE $\rightarrow$ YDG & $(+)$ etki \\
\hline Neves ve Caetano, 2006; Stinglhamber vd., 2006 & $\mathrm{EA} \rightarrow \mathrm{YDG}$ & $(+)$ etki \\
\hline Akram vd., 2018 & $\mathrm{YA} \rightarrow \mathrm{YDG}$ & $(+)$ etki \\
\hline Afsar ve Saeed, 2010 & Y.Dü. $\rightarrow$ YDG & $(+)$ etki \\
\hline Afsar ve Saeed, 2010; Frazier vd., 2015 & Y.Be. $\rightarrow$ YDG & $(+)$ etki \\
\hline Afsar ve Saeed, 2010; Frazier vd., 2015 & YYS $\rightarrow$ YDG & $(+)$ etki \\
\hline Özkara, 2019 & YPY $\rightarrow$ YDG & $(+)$ etki \\
\hline Özkara ve Sağlam Arı, 2019 & $\mathrm{EL} \rightarrow \mathrm{YDG}$ & $(+)$ etki \\
\hline Asgari vd., 2008; Özkara ve Sağlam Arı, 2019 & $\mathrm{DL} \rightarrow \mathrm{YDG}$ & $(+)$ etki \\
\hline Özkara, 2019 & $\mathrm{OL} \rightarrow \mathrm{YDG}$ & $(+)$ etki \\
\hline Afsar ve Saeed, 2010; Frazier vd., 2015 & $\mathrm{AGE} \rightarrow \mathrm{YDG}$ & $(+)$ etki \\
\hline Ji ve Jan, 2020 & İYA $\rightarrow$ YDG & (-) etki \\
\hline Afsar ve Saeed, 2010; Canipe, 2006; Sağlam Arı, 2003a & YDG $\rightarrow$ ÖB & $(+)$ etki \\
\hline Tan ve Tan, 2000 & $\mathrm{YDG} \rightarrow \mathrm{YT}$ & $(+)$ etki \\
\hline Sarıkaya, 2019 & YDG $\rightarrow$ İT & $(+)$ etki \\
\hline Akram vd., 2018 & $\mathrm{YDG} \rightarrow \mathrm{YB}$ & $(+)$ etki \\
\hline Lewicka vd., 2018 & YDG $\rightarrow \mathrm{S}$ & $(+)$ etki \\
\hline Afacan Fındıklı vd., 2010; Sağlam Arı, 2003b & $\mathrm{YDG} \rightarrow \mathrm{PG}$ & $(+)$ etki \\
\hline Holland vd., 2017 & YDG $\rightarrow$ İş.T & $(+)$ etki \\
\hline $\begin{array}{l}\text { Akram vd., 2018; Chen vd., 2008; Frazier vd., 2015; } \\
\text { Lu, } 2014\end{array}$ & YDG $\rightarrow$ ÖVD & $(+)$ etki \\
\hline Abuelhassan vd., 2018 & YDG $\rightarrow$ Ye.D & $(+)$ etki \\
\hline Frazier vd., 2015 & YDG $\rightarrow$ İP & $(+)$ etki \\
\hline Canipe, 2006 & YDG $\rightarrow$ İAN & (-) etki \\
\hline Sağlam Arı ve Tunçay, 2010 & YDG $\rightarrow \mathrm{T}$ & (-) etki \\
\hline Sağlam Arı ve Tunçay, 2010 & YDG $\rightarrow \mathrm{D}$ & (-) etki \\
\hline
\end{tabular}

Not: YDG: Yöneticiye Duyulan Güven; LÜE: Lider-Üye Etkileşiminin Kalitesi; EA: Etkileşimsel Adalet; YA: Yönetsel Adalet; Y.Dü.: Yöneticinin Dürüstlüğü; Y.Be.: Yöneticinin Becerisi; YYS: Yöneticinin Yardımseverliği; YPY: Yöneticinin Politik Yetisi; EL: Etkileşimci Liderlik; DL: Dönüşümcü Liderlik; OL: Otantik Liderlik; AGE: Astların Güven Eğilimi; IYA: İstismarcı Yönetim Anlayışı; ÖB: Örgütsel Bağlılık; YT: Yöneticiden Tatmin; İT: İş Tatmini; YB: Yöneticiye Bağllık; S: Sadakat; PG: Psikolojik Güçlendirme; İş.T: İşe Tutkunluk; ÖVD: Örgütsel Vatandaşlık Davranışları; Ye.D: Yenilikçi Davranışlar; İP: İş Performansı; İAN: İşten Ayrılma Niyeti; T: Tükenmişlik; D: Duyarsızlık 
Tablo 3. Algılanan Örgütsel Destek ve Yönetici Desteği ile Güven Arasındaki İlişkiler

\begin{tabular}{|c|c|c|}
\hline Çalışmalar & $\begin{array}{l}\text { Değisskenler } \\
\text { ve İlişkinin Yönü }\end{array}$ & Sonuçlar \\
\hline $\begin{array}{l}\text { Celep ve Eler Yilmazturk, 2012; DeConinck, 2010; } \\
\text { Eğriboyun, 2013; Keskinkılıç Kara vd., 2015; Kestek, } \\
\text { 2016; Sezgin, 2015; Tangi, 2019; Yakut Özek, 2016; } \\
\text { Yılmaz, } 2014\end{array}$ & ÖD $\leftarrow \rightarrow$ ÖG & $(+)$ ilişki \\
\hline $\begin{array}{l}\text { Canipe, 2006; Eğriboyun, 2013; Paille vd., 2010; } \\
\text { Stinglhamber vd., 2006; Tangi, 2019; Uysal, } 2019\end{array}$ & ÖD $\leftarrow \rightarrow$ Örg.G & $(+)$ ilişki \\
\hline $\begin{array}{l}\text { Canipe, 2006; Keskinkılıç Kara vd., 2015; Tangi, 2019; } \\
\text { Uysal, } 2019\end{array}$ & ÖD $\leftarrow \rightarrow$ IAG & $(+)$ ilişki \\
\hline $\begin{array}{l}\text { Asgari vd., 2008; Canipe, 2006; Eğriboyun, 2013; } \\
\text { Keskink1lıc Kara vd., 2015; Tangi, 2019; Uysal, } 2019\end{array}$ & ÖD $\leftarrow \rightarrow$ YDG & $(+)$ ilişki \\
\hline Aksoy, 2019 & $\mathrm{YD} \leftarrow \rightarrow$ ÖG & $(+)$ ilişki \\
\hline $\begin{array}{l}\text { Ji ve Jan, 2020; } \quad \text { Keskinkılıç } \\
\text { Yakut Özek, } 2016\end{array}$ & $\mathrm{YD} \leftarrow \rightarrow$ İAG & $(+)$ ilişki \\
\hline Celep ve Eler Yilmazturk, 2012; Y1lmaz, 2014 & ÖG $\rightarrow$ ÖD & (+) etki \\
\hline Canipe, 2006 & Örg.G $\rightarrow$ ÖD & $(+)$ etki \\
\hline Canipe, 2006 & İAG $\rightarrow$ ÖD & (+) etki \\
\hline Canipe, 2006; Celep ve Eler Yilmazturk, 2012 & YDG/Yön.DG $\rightarrow$ ÖD & $(+)$ etki \\
\hline Keskink1lıç Kara vd., 2015; Tangi, 2019 & YD $\rightarrow$ ÖG & $(+)$ etki \\
\hline $\begin{array}{lrrrr}\text { DeConinck, } & \text { 2010; } & \text { Ksiazek } & \text { vd., } & 2016 ; \\
\text { Rahmani ve } \quad \text { Heydari, } & 2017 ; & \text { Sezgin, } & 2015 ; \\
\text { Singh ve Malhotra, 2015 } & & & \end{array}$ & ÖD $\rightarrow$ ÖG & $(+)$ etki \\
\hline 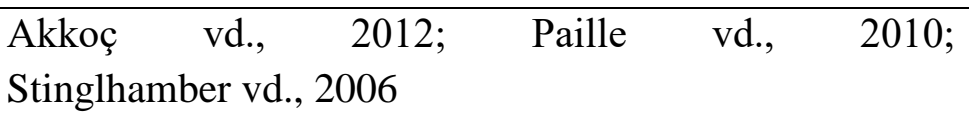 & ÖD $\rightarrow$ Örg.G & $(+)$ etki \\
\hline
\end{tabular}

Not: ÖD: Örgütsel Destek; YD: Yönetici Desteği; ÖG: Örgütsel Güven; Örg.G: Örgüte Güven; İAG: İş Arkadaşına Güven; YDG: Yöneticiye Duyulan Güven; Yön.DG: Yönetime Duyulan Güven

\subsection{Araştırma Kapsamında Ele Alınan Değişkenler Arasındaki İlişkiler}

Alanyazındaki ampirik çalışmalar (Abuelhassan vd., 2018; Akram vd, 2018; Chen vd., 2008; DeConinck, 2010; Holland vd., 2017; Ji ve Jan, 2020; Keskinkılıç Kara vd., 2015; Lewicka vd., 2018; Neves ve Caetano, 2006; Stinglhamber vd., 2006; Taş vd., 2019; Yakut Özek, 2016); algılanan yönetici desteğiyle çalışanların yöneticilerine duydukları güven arasında anlamlı ve olumlu bir ilişki olduğunu istatistiksel olarak ispatlamaktadır. Ayrıca literatürdeki görgül çalışmalara (Akram vd, 2018; DeConinck, 2010; Holland vd., 2017; Ji ve Jan, 2020; Neves ve Caetano, 2006; Stinglhamber vd., 2006; Taş vd., 2019) göre; algılanan yönetici desteği, çalışanların yöneticilerine duydukları güveni anlamlı ve pozitif bir şekilde etkilemektedir. 
Literatürdeki görgül çalışmalar (Ergeneli vd., 2007; Lu, 2014; McAllister, 1995; Newman vd., 2014; Özkara ve Sağlam Arı, 2019; Özkara, 2019; Sağlam Arı ve Tunçay, 2010; Sağlam Ar1, 2003b; Schaubroeck vd., 2011; Taş vd., 2019; Tunçay, 2009; Zhu ve Akhtar, 2014a; Zhu ve Akhtar, 2014b); bilişsel ve duygusal güven arasında anlamlı ve olumlu bir ilişki olduğunu ortaya koymaktadır. Ayrıca alanyazındaki ampirik çalışmalara (McAllister, 1995; Newman vd., 2014; Schaubroeck vd., 2011; Taş vd., 2019) göre; bilişsel güven, duygusal güveni anlamlı ve pozitif bir şekilde etkilemektedir.

Tüm bu bilgilerden hareketle, çalışma kapsamında; algılanan yönetici desteği düzeyindeki artışın çalışanların bir üst yöneticilerine duydukları hem bilişsel hem de duygusal güven düzeyilerini yükseltmesi, ayrıca bilişsel güven düzeyindeki artışın da duygusal güven düzeyini yükseltmesi beklenmektedir.

\section{4. Çalışmanın Araştırma Modeli ve Hipotezi}

Literatürdeki kuramsal bilgiler ve görgül çalışmalar 1şı̆̆ında, çalışmanın araştırma modeli Şekil 1'deki gibi kurulmuştur. Çalışmanın araştırma modelinden hareketle çalışma kapsamında geliştirilen araştırma hipotezi ise şu şekildedir:

H1: Çalışanların bir üst yöneticilerine duydukları bilişsel güven, algılanan yönetici desteği ile çalışanların bu yöneticilerine duydukları duygusal güven arasındaki ilişkide aracılık rolüne sahiptir.

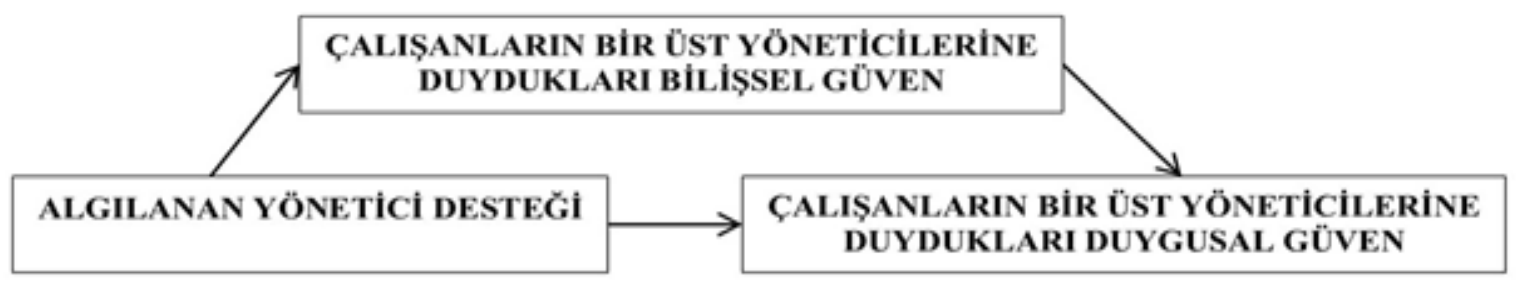

Şekil 1. Araştırma Modeli

\section{Yöntem}

\section{1.Örneklem}

Araştırmanın evreni; Türkiye'nin doğusundaki bir devlet üniversitesinde akademik ve idari birimlerde görev yapmakta olan toplam 419 çalışanı içermektedir. Örneklem seçilmeyerek, evrenin tamamına ulaşılmaya çalışılmıştır. Araştırmanın verileri; 2019 y1lı içerisinde anket yöntemi kullanılarak, kapalı zarf usulüyle dağıtılıp toplanmıştır. 419 çalışanın 316'sına anket dağıtılmıştır. Anket dağıtılan 316 çalışanın 266'sı geri dönüş yapmıştır. Geri dönüş oranı yaklaşık \%84'tür. Ancak bu anketlerin yalnızca 210 tanesi düzgün bir şekilde doldurulmuştur. Çalışma kapsamında; Tabachnick ve Fidell (2013)'ün veri setinin kontrolü ve verinin analize 
hazır hale getirilmesi için önerdiği dört aşamalı yöntem kullanılmıştır. Bu ön analiz yöntemi; "veri setinin doğruluğu”, "eksik veri”, "normallik testi” ve "çoklu bağlantı" analizlerinden oluşmaktadır. Ön analizlerin sonucunda; çalışmanın araştırma modelindeki tüm ölçek maddelerine ilişkin basıklık ve çarpıklık değerlerinin \pm 1.5 aralığında olduğu belirlenmiş ve verinin normal dağılım gösterdiği varsayılmıştır. Ayrıca araştırmaya dahil edilen katılımcı sayısı 210 olarak netleşmiştir. Araştırma evreninin \%50.12'sine, yani yarıdan fazlasına ulaşılmıştır. Çalışma kapsamında ulaşılan bu oran yeterli görülmüş ve bu oranın evreni temsil eder nitelikte olduğu varsayılmıştır.

\subsection{Veri Toplama Araçları}

Anket formu üç kısımdan oluşmaktadır. Birinci kısımda; algılanan yönetici desteğini ölçmek için Giray ve Şahin (2012) tarafından geliştirilen 11 maddelik ölçek, ikinci kısımda ise çalışanların bir üst yöneticilerine duydukları bilişsel ve duygusal güveni ölçmek için McAllister (1995) tarafından geliştirilen ve Sağlam Arı'nın (2003b) Türkçe’ye uyarladığı 10 maddelik ölçek kullanılmıştır. Algılanan yönetici desteği ve güven ölçekleri 5’li Likert tipi ölçme düzeyinde "Kesinlikle katılmıyorum (1)-Tamamen katılıyorum (5)" şeklinde derecelendirilmiştir. Son olarak, üçüncü kısımda; katılımcılardan demografik özelliklerini belirlemeye yönelik bazı sorulara cevap vermeleri istenmiştir. Anket sorularının tamamı ast konumunda çalışanlar tarafından cevaplanmıştır.

\section{Bulgular}

\subsection{Betimsel Bulgular}

Katılımcılara dair demografik özellikler sıklık (n) ve yüzde (\%) bazında Tablo 4'te görülmektedir.

Tablo 4. Katılımciların Demografik Özellikleri

\begin{tabular}{|l|l|l|l|}
\hline Demografik Özellikler & Kategoriler & Siklık(n) & Yüzde (\%) \\
\hline Cinsiyet & Kadın & 51 & 24.3 \\
\cline { 2 - 4 } & Erkek & 159 & 75.7 \\
\hline Yaş & $18-28$ & 14 & 6.7 \\
\cline { 2 - 4 } & $29-38$ & 145 & 69.0 \\
\cline { 2 - 4 } & $39-48$ & 43 & 20.5 \\
\cline { 2 - 4 } & $49-58$ & 8 & 3.8 \\
\hline \multirow{5}{*}{ ğitim Düzeyi } & Lise & 15 & 7.1 \\
\cline { 2 - 4 } & Ön lisans & 20 & 9.5 \\
\cline { 2 - 4 } & Lisans & 78 & 37.1 \\
\hline
\end{tabular}


Taş, A., Özkara, Z. U., Aydıntan, B. / Journal of Yasar University, 2021, 16/61, 147-169

\begin{tabular}{|l|l|l|l|}
\hline \multirow{4}{*}{ Birim } & Yüksek Lisans & 41 & 19.5 \\
\cline { 2 - 4 } & Doktora & 56 & 26.7 \\
\hline \multirow{5}{*}{ Çalışma Süresi } & İdari & 101 & 48.1 \\
\cline { 2 - 4 } & Akademik & 109 & 51.9 \\
\cline { 2 - 4 } & 1 y1ldan az & 12 & 5.7 \\
\cline { 2 - 4 } & $1-5$ & 91 & 43.3 \\
\cline { 2 - 4 } & $6-10$ & 81 & 38.6 \\
\cline { 2 - 4 } & $11-15$ & 16 & 7.6 \\
\cline { 2 - 4 } & $16-20$ & 6 & 2.9 \\
\cline { 2 - 4 } & $21-25$ & 4 & 1.9 \\
\hline
\end{tabular}

\subsection{Geçerlilik Analizi}

Anderson ve Gerbing (1988)'e göre; öncelikle modelin yapı geçerliliği araştırılmalı, daha sonra araştırma modeli yapısal eşitlik modellemesi ile test edilmelidir. "AMOS 24" programında çalışmanın 3 değişken ve 21 maddeden oluşan araştırma modeline en yüksek olabilirlik (maximum likelihood) yöntemi kullanılarak bütün bir yapıda doğrulayıcı faktör analizi (overall confimatory factor analysis) yapılmıştır. Hair ve diğerlerinin (2010) önerisi doğrultusunda doğrulayıcı faktör analiziyle elde edilen faktör yükleri, standart hata kovaryans değerleri ve modifikasyon indeksleri incelenmiştir.

Elde edilen sonuçlara göre; araştırma modelindeki tüm ölçek maddelerinin anlamlı olduğu tespit edilmiştir. Ayrıca Şekil 2 ve Tablo 5'te görüldüğü üzere standardize edilmiş yol katsayıları algılanan yönetici desteği ölçeğinin maddeleri için .75-.87 arasında; bilişsel güven ölçeğinin maddeleri için .80-.87 arasında, duygusal güven ölçeğinin maddeleri için ise .81-.89 arasında değişmektedir. Tüm faktör yükü değerlerinin .40’tan yüksek olması (Hair vd., 2010) nedeniyle faktör yüklerinin tamamı yeterli düzeydedir.

Tablo 6'da görüldügü üzere araştırma modeline ait tüm uyum indeks değerleri yeterli düzeydedir $\left[\Delta \mathrm{X}^{2} / \mathrm{sd}=2.557, \mathrm{CFI}=.931, \mathrm{TLI}=.922, \mathrm{RMSEA}=.086\right.$, HOELTER.05= 97]. Böylece araştırma modelindeki ölçek maddelerinin hata terimleri birleştirilmeden ve hiçbir ölçek maddesi analizden çıkarılmadan araştırma modelinin yapı geçerliliği sağlanmıştır ve araştırma hipotezinin test edilebilmesi için gerekli zemin hazırlanmıştır. 


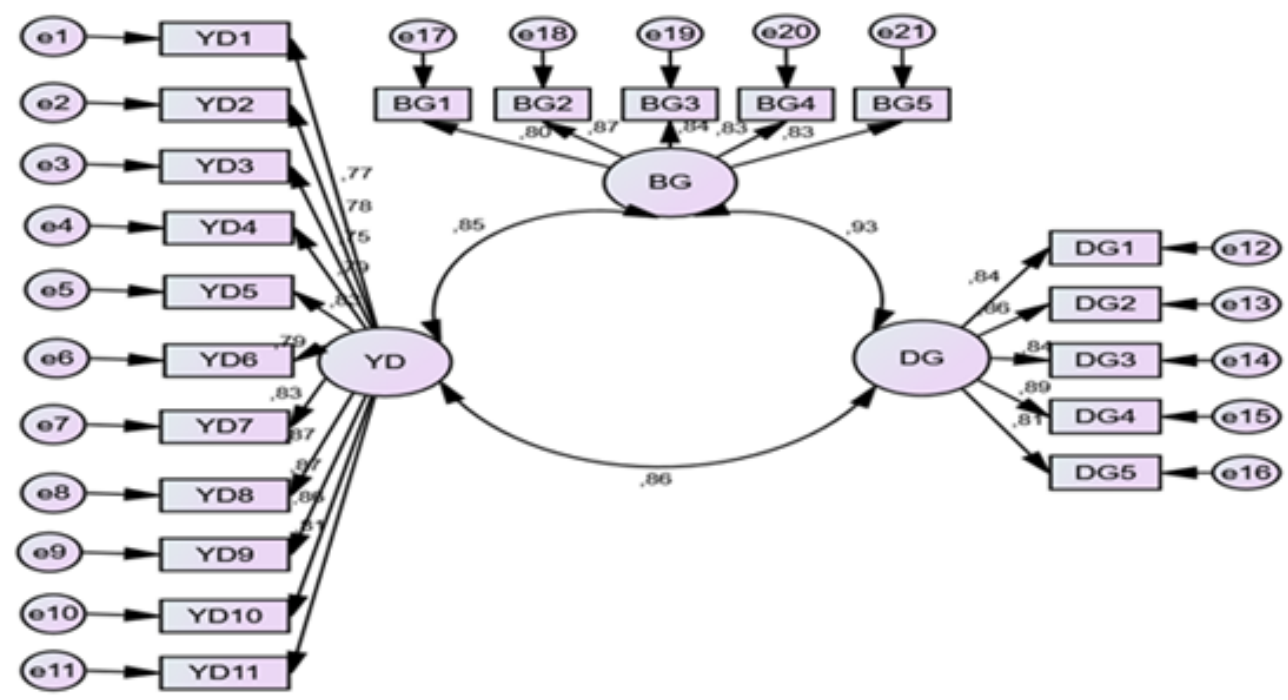

Şekil 2. Bütün Bir Yapıda Doğrulayıcı Faktör Analizi

Not: YD: Yönetici Desteği; BG: Bilişsel Güven; DG: Duygusal Güven

Tablo 5. Ölçek Maddelerine İlişkin Faktör Yükleri

\begin{tabular}{|c|c|c|c|}
\hline \multirow{2}{*}{ Maddeler } & \multicolumn{3}{|c|}{ Faktör Yükleri } \\
\hline & 1 & 2 & 3 \\
\hline YD1: Bir üst amirim bir işi yaptığımda beni takdir eder & .77 & & \\
\hline$Y D 2:$ Bir üst amirim işimi yapmamda yardımcı olur & .78 & & \\
\hline YD3: Bir üst amirim sağlık, mutluluk gibi genel durumumla ilgilenir & .75 & & \\
\hline YD4: Bir üst amirim görüşlerimi dikkate alır & .79 & & \\
\hline YD5: Bir üst amirim işler çıkmaza girdiğinde güvenebileceğim biridir & .83 & & \\
\hline $\begin{array}{l}\text { YD6: Bir üst amirim işimle ilgili sorunları dinlemeye her zaman için } \\
\text { hazırdır }\end{array}$ & .79 & & \\
\hline YD7: Bir üst amirim çalışanlarını başkalarına karşı canla başla savunur & .83 & & \\
\hline $\begin{array}{l}\text { YD8: Bir üst amirim işime yönelik amaç ve isteklerimi öğrenmek için } \\
\text { bana zaman ayırır }\end{array}$ & .87 & & \\
\hline $\begin{array}{l}\text { YD9: Bir üst amirim işimde önemli bir şey başardığımda takdir edilmemi } \\
\text { sağlar }\end{array}$ & .87 & & \\
\hline $\begin{array}{l}\text { YD10: Bir üst amirim bilmeden bir hata yaptığımda beni kurumdaki diğer } \\
\text { kişilere karş1 savunur }\end{array}$ & .86 & & \\
\hline $\begin{array}{l}\text { YD11: Bir üst amirim performansımı nasıl geliştireceğim konusunda bana } \\
\text { yol gösterir }\end{array}$ & .81 & & \\
\hline BG1: Bir üst amirim kendini işine adayan bir profesyoneldir & & .80 & \\
\hline $\begin{array}{l}B G 2: \text { Var olan bilgilere dayanarak, bir üst amirimin işe uygunluğu ve } \\
\text { yeteneği-ehliyeti konusunda kuşkum yoktur }\end{array}$ & & .87 & \\
\hline $\begin{array}{l}\text { BG3: Bir üst amirimin işimi güçleştirecek dikkatsizlikler ve hatalar } \\
\text { yapmayacağından eminim }\end{array}$ & & .84 & \\
\hline $\begin{array}{l}B G 4: \text { İş ortamında çoğu kişi, çok yakın olmasalar da iş arkadaşı olarak bir } \\
\text { üst amirime güvenir ve saygı duyar }\end{array}$ & & .83 & \\
\hline $\begin{array}{l}\text { BG5: Bir üst amirimle çalışan diğer arkadaşlarım onun güvenilir } \\
\text { olduğunu düşünür }\end{array}$ & & .83 & \\
\hline $\begin{array}{l}\text { DG1: Bir üst amirimle ilişkimiz paylaşımcı bir yapıdadır. Karşılıklı } \\
\text { olarak fikir, duygu ve beklentilerimizi serbestçe paylaşırız }\end{array}$ & & & .84 \\
\hline DG2: Bir üst amirimle işimde karşılaştığım güçlükler hakkında raha & & & .86 \\
\hline
\end{tabular}




\begin{tabular}{|l|c|c|}
\hline konuşabilirim ve bilirim ki beni dinlemeye her zaman isteklidir & & \\
\hline $\begin{array}{l}\text { DG3: Eğer ikimizden birisi başka bir işe geçmek durumunda kalır ve artık } \\
\text { bir arada çalışamazsak, her ikimiz de üzüntü duyarız }\end{array}$ & .84 \\
\hline $\begin{array}{l}\text { DG4: Eğer bir üst amirimle karşılaştığım problemleri paylaşırsam, bu } \\
\text { konuda yapıcı ve ilgili bir tavır sergileyeceğini bilirim }\end{array}$ & .89 \\
\hline $\begin{array}{l}\text { DG5: Her ikimizin de zaman içinde iş ilişkimize dostluk-arkadaşlık } \\
\text { ilişkilerini de katabildiğimizi söyleyebilirim }\end{array}$ & & .81 \\
\hline
\end{tabular}

Not: YD: Yönetici Desteği; BG: Bilişsel Güven; DG: Duygusal Güven

Tablo 6. Doğrulayıcı Faktör Analizi Uyum İndeks Değerleri

\begin{tabular}{|l|l|l|l|l|l|}
\hline Uyum Indeksleri & $\Delta X^{2} / s d$ & $C F I$ & $T L I$ & $R M S E A$ & HOELTER.05 \\
\hline Eşik Değerler & $<5.0^{*}$ & $\geq 0.90^{* *}$ & $\geq 0.90^{* * *}$ & $<0.10^{* * * *}$ & $>75^{* * * * * *}$ \\
\hline $\begin{array}{l}\text { Modelin } \\
\text { Değerleri }\end{array}$ & 2.557 & 0.931 & 0.922 & 0.086 & 97 \\
\hline
\end{tabular}

Not: *Bentler ve Bonett (1980); **Hu ve Bentler (1999); ***Meydan ve Şeşen (2011); ****Browne ve Cudeck (1993);*****Emhan, Kula ve Töngür (2013)

\subsection{Güvenilirlik ve Korelasyon Analizleri}

Araştırma modelinin yapı geçerliliği sağlandıktan sonra güvenilirlik ve korelasyon analizleri yapılmıştır. Tablo 7'de görüldüğü üzere araştırma kapsamında ele alınan algılanan yönetici desteği, çalışanların bir üst yöneticilerine duydukları bilişsel ve duygusal güven ölçeklerine ait Cronbach Alpha güvenilirlik katsayıları sırasıyla .95, .91 ve .92 olarak hesaplanmıştır. Bu değerler; arzu edilen “.70” minimum Cronbach Alpha değerinin (Hair vd., 2010) üzerindedir.

Pearson korelasyon analizi sonucunda; algılanan yönetici desteği ile bilişsel güven $(r=.80$; $\mathrm{p}<.01)$, bilişsel güven ile duygusal güven $(\mathrm{r}=.84 ; \mathrm{p}<.01)$ ve algilanan yönetici desteği ile duygusal güven $(r=.80 ; p<.01)$ arasında anlamlı ve pozitif yönlü ilişkiler tespit edilmiştir. Demografik değişkenlerden cinsiyet ile araştırma değişkenleri arasında anlamlı ilişkiler tespit edilmemiştir.

Ayrıca, Tablo 7'nin altında yer alan Not 2'deki değerler incelendiğinde; algılanan yönetici desteğiyle bilişsel güven değişkenleri arasında otokorelasyon ve çoklu bağlantı (multicollinearity) sorunları olmadığı görülmektedir (Büyüköztürk, 2012; Kalaycı, 2010).

Tablo 7. Tanımlayıcı İstatistikler, Güvenilirlik ve Korelasyon Analizi Sonuçları

\begin{tabular}{|c|c|c|c|c|c|c|}
\hline Değişkenler & Ort. & $S S$ & 1 & 2 & 3 & 4 \\
\hline \multicolumn{7}{|l|}{ Cinsiyet } \\
\hline Algllanan Yönetici Desteği & 3.54 & 1.09 & .09 & $(.95)$ & & \\
\hline Bilişsel Güven & 3.70 & 1.11 & .01 & $.80 * *$ & $(.91)$ & \\
\hline Duygusal Güven & 3.50 & 1.16 & .11 & $.80 * *$ & $.84 * *$ & $(.92)$ \\
\hline
\end{tabular}

Not 1: **p<.01; Parantez içindeki değerler Cronbach Alpha güvenilirlik katsayısıdır. 
Not 2: Varyans oranları (tolerans değeri:0.346/0.346 >0.2, VIF değeri:2.891/2.891<10); Durum indeksi değerleri (CI değerleri:1.000/7.496/13.480<30); Durbin Watson (1.5<DW:2.078<2.5)

\subsection{Araştırma Hipotezinin Test Edilmesi}

Geçerlilik, güvenilirlik ve korelasyon analizleri yapıldıktan sonra, çalışmanın araştırma hipotezi test edilmiştir. Araştırma hipotezinde; çalışanların bir üst yöneticilerine duydukları bilişsel güvenin algılanan yönetici desteği ile çalışanların bu yöneticilerine duydukları duygusal güven arasında aracı rol üstlendiği ifade edilmektedir. Literatürdeki bazı çalışmalara göre (Hu ve Bentler, 1995; Kline, 2005); yapısal eşitlik modellemesinin yapılabilmesi için veri seti büyüklüğünün minimum 200 olması gerekmektedir. Bu çalışmada da veri setinin 210 katılımcıdan oluştuğu göz önüne alınarak, çalışmanın araştırma hipotezi "AMOS" programında yapısal eşitlik modellemesiyle test edilmiştir. Ayrıca yapısal eşitlik modellemesinden sonra, araştırma hipotezi interaktif ortamda Sobel testi kullanılarak da sınanmıştır. Bu çalışmada; aracılığın test edilmesi amacıyla Baron ve Kenny (1986) tarafindan önerilen dört koşullu yöntemi temel alan, Meydan ve Şeşen (2011) tarafından kullanılan yol takip edilmiştir. Bu kapsamda; ilk koşulun test edilmesi için Şekil 3 ’te görülen sadece bağımsız ve bağımlı değişkenin yer aldığı birinci yapısal eşitlik modellemesi kurulmuştur.

Birinci yapısal eşitlik modellemesi sonucunda elde edilen uyum indeks değerlerinin $\left[\Delta \mathrm{X}^{2} / \mathrm{sd}=2.823, \mathrm{CFI}=.938, \mathrm{TLI}=.928, \mathrm{RMSEA}=.093\right.$, HOELTER.05=92] Tablo 6'daki eşik değerlerle karşılaştırıldığında yeterli düzeyde olduğu görülmektedir. Bu durumda, çalışmanın araştırma modelindeki ölçek maddelerinin hata terimleri birleştirilmeden ve hiçbir ölçek maddesi analizden çıkarılmadan çalışmaya devam edilmiştir. Birinci yapısal eşitlik modellemesi sonucuna göre; algılanan yönetici desteği duygusal güveni pozitif ve anlamlı bir şekilde etkilemektedir $(\beta=0.86 ; \mathrm{p}<0.01) . \mathrm{Bu}$ durumda; aracılığa ilişkin birinci koşul sağlanmıştır (Bkz. Şekil 5). 


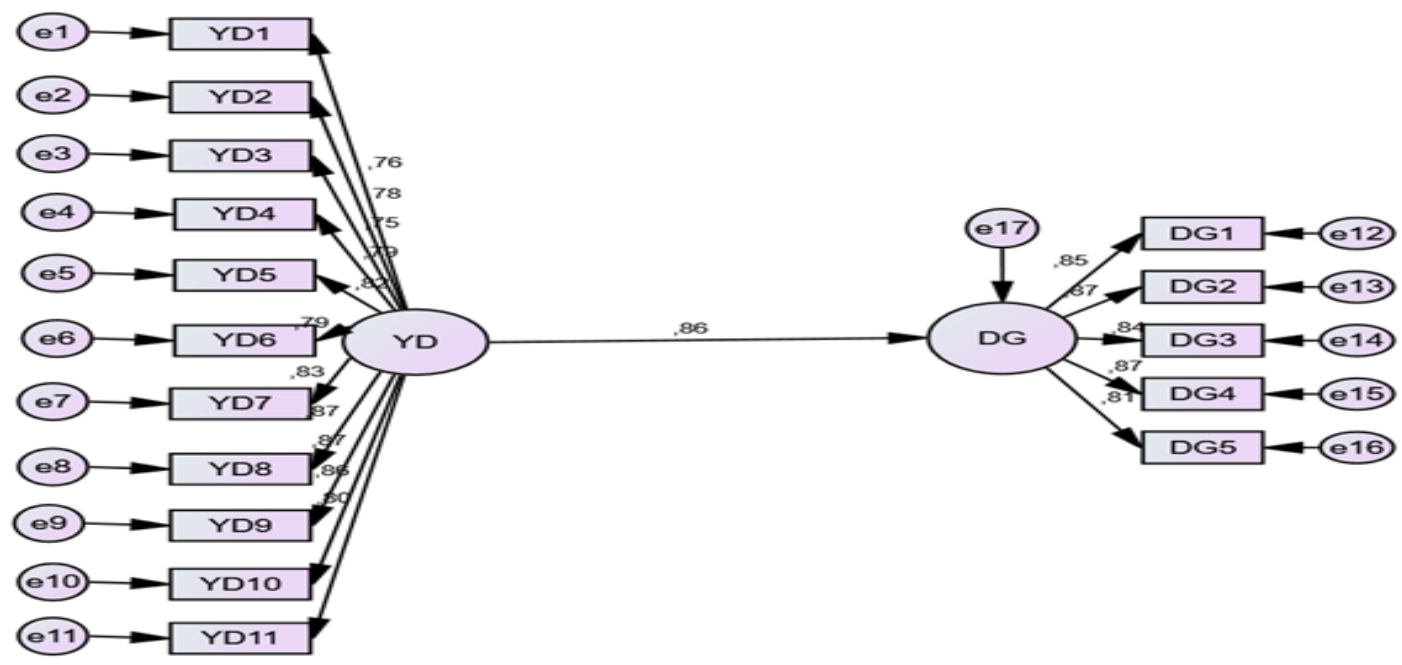

Şekil 3. Birinci Yapısal Eşitlik Modellemesi

Not: YD: Yönetici Desteği; DG: Duygusal Güven

Birinci koşul sağlandıktan sonra, diğer koşulların da incelenmesi amacıyla ilk modele aracı değişken eklenerek Şekil 4'te görülen ikinci yapısal eşitlik modellemesi kurulmuştur.

İkinci yapısal eşitlik modellemesi sonucunda elde edilen uyum indeks değerlerinin $\left[\Delta \mathrm{X}^{2} / \mathrm{sd}\right.$ =2.557, CFI=.931, TLI=.922, RMSEA=.086, HOELTER.05=97] Tablo 6' daki eşik değerlerle karşılaştırıldığında yeterli düzeyde olduğu görülmektedir. Bu durumda, çalışmanın araştırma modelindeki ölçek maddelerinin hata terimleri birleştirilmeden ve hiçbir ölçek maddesi analizden çıkarılmadan çalışmaya devam edilmesine karar verilmiştir. İkinci yapısal eşitlik modellemesi sonuçlarına göre; algılanan yönetici desteği bilişsel güveni anlamlı ve pozitif bir şekilde etkilerken $(\beta=0.85 ; \mathrm{p}<0.01)$, bilişsel güven de duygusal güveni anlamlı ve pozitif bir şekilde etkilemektedir $(\beta=0.73 ; \mathrm{p}<0.01)$. Bu durumda; aracılığa ilişkin ikinci ve üçüncü koşullar sağlanmıştır. Algılanan yönetici desteği duygusal güveni birinci modelde olduğu gibi anlamlı ve olumlu bir şekilde etkilemektedir $(\beta=0.23 ; \mathrm{p}<0.001)$. Bununla birlikte dolaylı etki $(\beta=0.23)$ birinci modeldeki direkt etkiden $(\beta=0.86)$ daha düşüktür; ancak hâlâ anlamlıdır. Böylece aracılığa dair dördüncü koşul da sağlanmıştır. Bu durum; bilişsel güvenin kısmi aracılık rolü olduğuna işaret etmektedir (Bkz. Şekil 5).

Yapısal eşitlik modellemesi ile dört koşul da sağlandıktan sonra, aracılık etkisinin anlamlı olup olmadığını tespit edebilmek için gerçekleştirilen Sobel testi sonucunda (Preacher ve Leonardelli, 2010); bilişsel güvenin algılanan yönetici desteğiyle duygusal güven arasındaki ilişkiye aracılık ettiği istatistiksel olarak ispatlanmıştır $(\mathrm{z}=6.292 ; \mathrm{p}<0.01)$. Dolayısıyla araştırma hipotezi desteklenmiştir. Ayrıca bilişsel güven değişkeni araştırma modelinde kısmi aracıl1k rolüne sahiptir. 


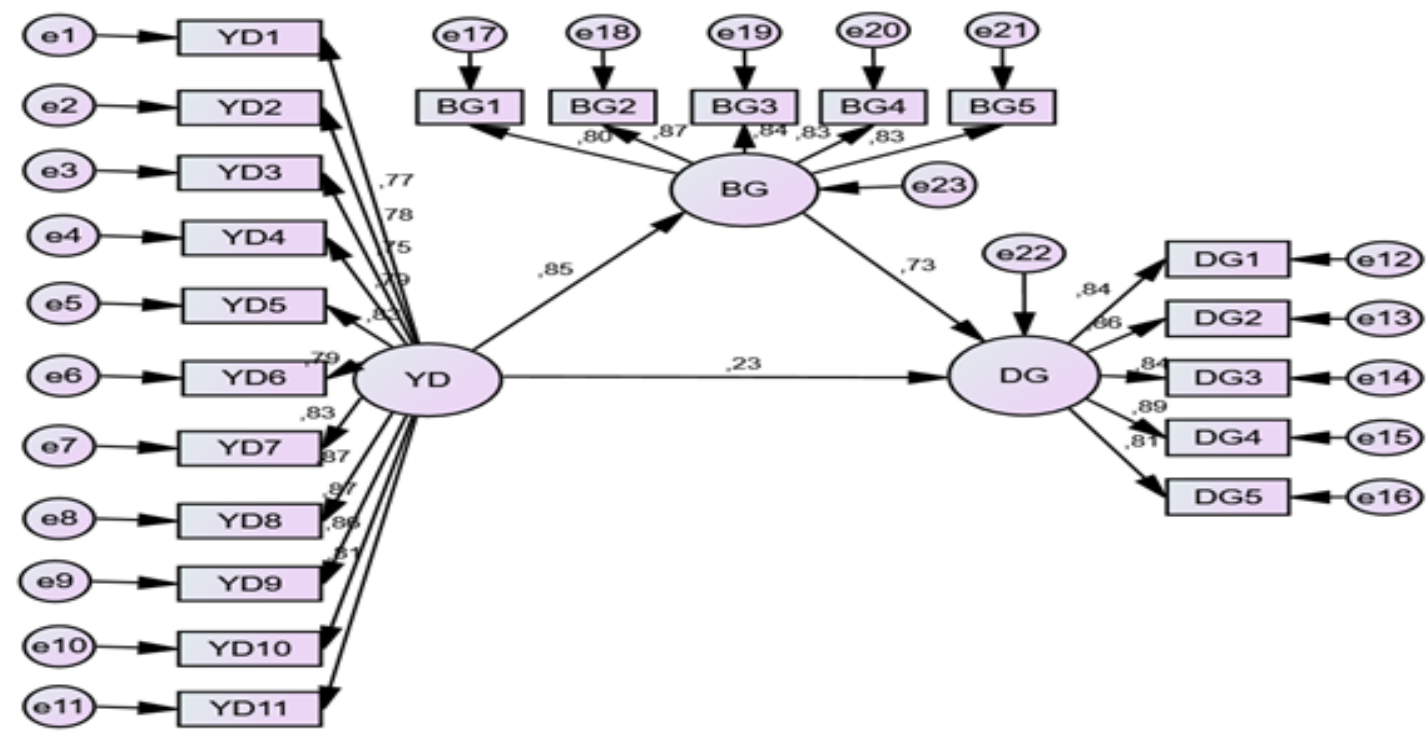

Şekil 4. İkinci Yapısal Eşitlik Modellemesi

Not: YD: Yönetici Desteği; BG: Bilişsel Güven; DG: Duygusal Güven

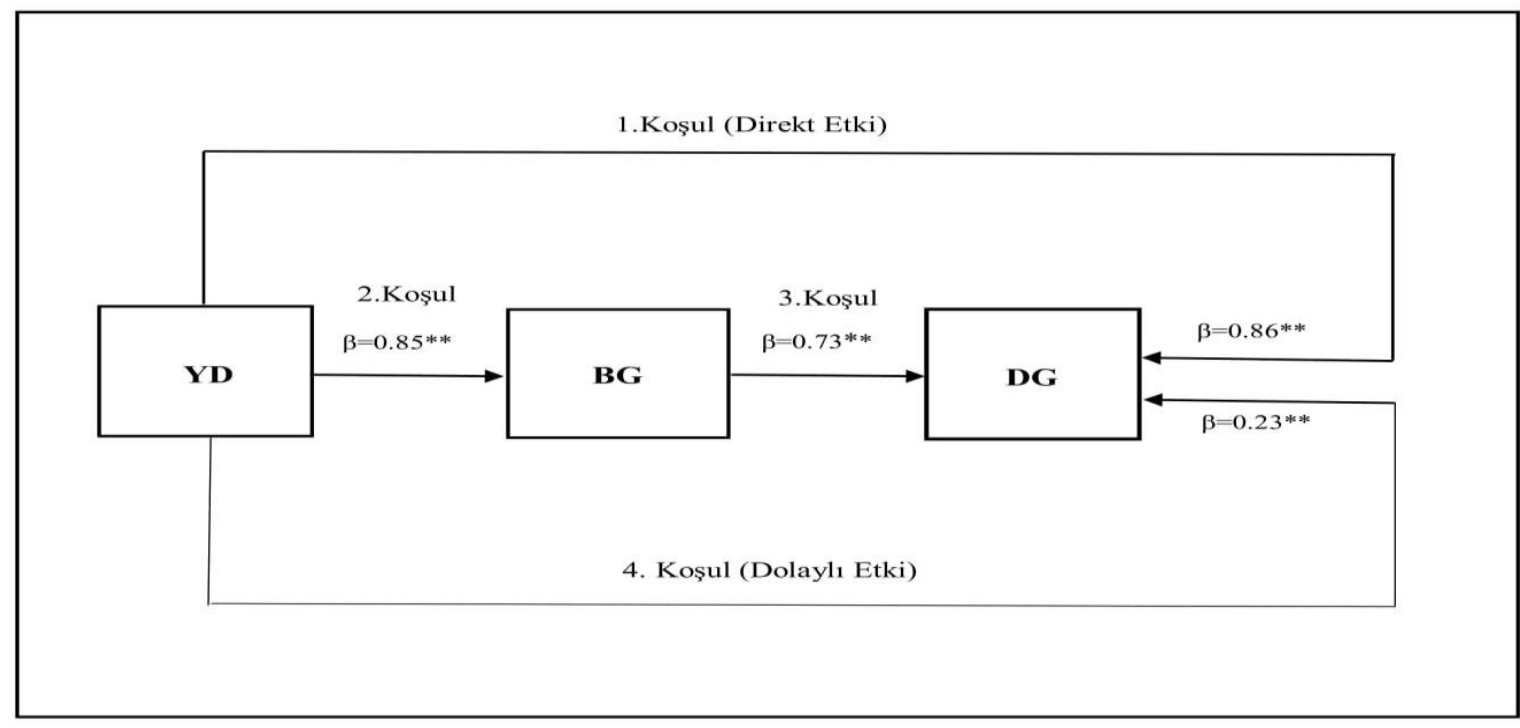

Şekil 5. Birinci ve İkinci Yapısal Eşitlik Modellemesi Sonuçlarının Şekil Yardımıyla Bir Arada Gösterimi

Not: ${ }^{*}$ p $<0.01 ; \beta=$ standardize edilmiş katsayı; YD:Yönetici Desteği; BG: Bilişsel Güven; DG: Duygusal Güven

\section{Sonuç ve Tartışma}

$\mathrm{Bu}$ çalışma çerçevesinde; algılanan yönetici desteğinin, çalışanların bir üst yöneticilerine duydukları duygusal güven üzerindeki etkisi araştırılarak bu ilişkide çalışanların bu yöneticilerine duydukları bilişsel güvenin üstlendiği aracılık rolü incelenmiştir.

Bu çalışmada; Taş ve diğerlerinin (2019) çalışmasında olduğu gibi aynı araştırma modeli kurulmuş ve bu model aynı araştırma evreni üzerinden anket yöntemiyle veri elde edilerek 
sınanmıştır. Ancak hem veri seti büyüklüğü yükseltilerek veri setinin evreni temsil etme kabiliyeti arttırılmış hem de bu sayede modeldeki değişkenlerin geçerliliği ve araştırma hipotezi SPSS programı yerine AMOS programında test edilmiştir. Yani araştırma kapsamında verinin analiz edilmesi hususunda yöntem değişikliğine gidilmiştir. Taş ve diğerlerinin (2019) çalışmasında; SPSS programında açımlayıcı faktör ve aracılı regresyon analizleri yapılırken, bu çalışmada ise doğrulayıcı faktör analizi ve yapısal eşitlik modellemesi gerçekleştirilmiştir. Yöntem değişikliğine rağmen, Taş ve diğerlerinin (2019) çalışmasıyla benzer sonuçların elde edildiği bu çalışmanın çalışmaya katılanlar bakımından araştırma sonuçlarına göre; algılanan yönetici desteği, çalşanların bir üst yöneticilerine duydukları bilişsel ve duygusal güven değişkenleri arasında beklenildiği üzere anlamlı ve olumlu yönde ikili ilişkiler vardır. Algılanan yönetici desteğinin çalışanların bir üst yöneticilerine duydukları bilişsel güven üzerinde, bilişsel güvenin de çalışanların bu yöneticilerine duydukları duygusal güven üzerinde beklenildiği gibi doğrudan, anlamlı ve olumlu etkileri bulunmaktadır. Ayrıca algılanan yönetici desteğinin çalışanların bir üst yöneticilerine duydukları duygusal güven üzerinde hem doğrudan hem de bilişsel güven üzerinden dolaylı bir şekilde anlamlı ve olumlu etkileri bulunmaktadır. $\mathrm{Bu}$ çalışma kapsamında; çalışanların bir üst yöneticilerine duydukları bilişsel güven, algılanan yönetici desteği ile çalışanların bu yöneticilerine duydukları duygusal güven arasındaki ilişkiye kısmi aracılik etmektedir.

Yöneticiye duyulan güvenin örgütsel başarıyı arttıracağı alanyazındaki kuramsal ve görgül çalışmalar dikkate alındığında aşikardır. Tüm bu bilgilerden hareketle, çalışma çerçevesinde; algılanan yönetici desteği düzeyindeki artışın çalışanların bir üst yöneticilerine duydukları bilişsel güven düzeyi üzerindeki yükseltici etkisi ve ayrıca hem algılanan yönetici desteği hem de bilişsel güven düzeylerindeki artışın çalışanların bu yöneticilerine duydukları duygusal güven düzeyi üzerindeki yükseltici etkileri yoluyla örgüte katkı sağlamanın mümkün olduğu sonucuna varılmaktadır.

Çalışanların hem amirlerinin işinin ehli ve disiplinli olduğuna dair inançlarının hem de işte ve iş dışında amirleri tarafından önemseneceklerine ve herhangi bir zorlukla karşılaştıklarında amirlerinden yardım alacaklarına dair inançlarının yükselmesi yoluyla örgüte katkı sağlanması hususunda; amirlerin çalışanlarına duygusal, maddi ve bilgisel anlamda verecekleri destek önemli bir rol oynayacaktır. Ayrıca astların amirlerinin işinin ehli ve disiplinli olduğuna dair inançlarının artması durumunda, işte ve iş dışında amirleri tarafından önemseneceklerine ve herhangi bir zorlukla karşılaştıklarında amirlerinden yardım alacaklarına dair inançları da yükselmektedir. O halde; yönetici desteği yanında yöneticinin 
işinin ehli ve disiplinli olmasının da duygusal güven oluşumu yoluyla örgütsel başarıyı arttırması beklenebilir. Bu bilgilerden hareketle; üniversitelerin akademik ve idari birimlerine yönetici seçimlerinin ve uyguladıkları yönetici geliştirme programlarının örgütsel başarının elde edilmesinde belirleyici olacağı söylenebilir. Bununla birlikte alanyazındaki bazı çalışmalarda (örn.: Afsar ve Saeed, 2010; Frazier vd., 2015; Nienaber vd., 2015); örgütlerde güven inşa edilmesinde yöneticilerin özellikleri, tutum ve davranışları yanında astların kişisel (demografik ve kişilik) özelliklerinin de etkili olabileceği tespit edilmiştir.

Araştırmanın gerçekleştirildiği üniversitede idari ve akademik birimlerde görev yapmakta olan erkek personel sayısı kadın personel sayısından oldukça fazladır. Bu durum; araştırmanın veri setine de yansıyarak araştırmanın bir kısıtı olmuştur. Gelecekteki çalışmalarda; çalışmanın araştırma modeli kadın sayısının daha fazla olduğu ya da kadın-erkek sayısının dengeli dağıldığı bir üniversitenin akademik ve idari personeli üzerinde de sınanarak sonuçlar karşılaştırılabilir. Ayrıca ast konumunda çalışanlara ait cinsiyet değişkeni ikinci dereceden bağımsız değişken (düzenleyici değişken), güven eğilimi birinci ya da ikinci dereceden bağımsız değişken, örgütsel destek aracı değişken, örgütsel güven sonuç değişkeni, lider (yönetici)-üye (ast) etkileşiminin kalitesi ise birinci dereceden bağımsız değişken ya da aracı değişken olarak çalışmanın araştırma modeline eklenerek model genişletilebilir. 
Taş, A., Özkara, Z. U., Aydıntan, B. / Journal of Yasar University, 2021, 16/61, 147-169

\section{KAYNAKÇA}

Abuelhassan, E. Abuelhassan, Naser A. Alareefi, Mohamed A. A. Abdelgawwad .2018. "Evaluating the Impact of Supervisor Support and Trust in Supervisor on Employee Innovative Behaviors: A Study in the UAE Five-Star Hotels”, Minia Journal of Tourism and Hospitality Research, 2(Özel Say1): 101-114.

Afacan Fındıklı, Mine .2014. “Algılanan Lider Desteği ve Algılanan Örgütsel Destek ile İşten Ayrılma Niyeti İlişkisinde Örgütsel Özdeşlemenin Aracılık Rolü: İstanbul'da Kamu Çalışanları Üzerine Bir Araştırma", İstanbul Üniversitesi Işsletme Fakültesi Işsletme İktisadı Enstitüsü Yönetim Dergisi, 25(77): 136-157.

Afacan Findıkl1, Mine, Adem Gulden, Fatih Semercioz .2010. "Subordinate Trust in Supervisor and Organization: Effects on Subordinate Perceptions of Psychological Empowerment", International Journal of Business and Management Studies, 2(1): 55-67.

Afsar, Bilal, Bilal Bin Saeed .2010. "Subordinate's Trust in the Supervisor and Its Impact on Organizational Effectiveness", The Romanian Economic Journal, 13(38): 3-25.

Akın, Mahmut .2008. "Örgütsel Destek, Sosyal Destek ve İş/aile Çatışmalarının Yaşam Tatmini Üzerindeki Etkileri”, Bozok Üniversitesi Sosyal Bilimler Enstitüsü Dergisi, 25(2): 141-170.

Akkoç, İrfan, Abdullah Çalışkan, Ömer Turunç .2012. "Örgütlerde Gelişim Kültürü ve Algılanan Örgütsel Desteğin İş Tatmini ve İş Performansına Etkisi: Güvenin Aracılık Rolü”, Yönetim ve Ekonomi, 19(1): 105-135.

Akram, Ammara, Muhammed Kamran, Muhammad Shahid Iqbal, Ume Habibah, Muhammad Atif I .2018. "The Impact of Supervisory Justice and Perceived Supervisor Support on Organizational Citizenship Behavior and Commitment to Supervisor: The Mediating Role of Trust", Cogent Business \& Management, 5(1): 1-31.

Aksoy, Cenk .2019. "The Relationship Between Organizational Justice, Supervisor Support, Organizational Trust, and Organizational Commitment: A Research in Aviation Sector", Avrasya Sosyal ve Ekonomi Araştırmaları Dergisi, 6(2): 349-356.

Anderson, James C., David W. Gerbing .1988. "Structural Equation Modeling in Practice: A Review and Recommended Two-step Approach", Psychological Bulletin, 103(3): 411-423.

Asgari, Ali, Abu Daud Silong, Aminah Ahmad, Bahaman Abu Samah .2008. "The Relationship Between Transformational Leadership Behaviors, Organizational Justice, Leader-member Exchange, Perceived Organizational Support, Trust in Management and Organizational Citizenship Behaviors", European Journal of Scientific Research, 23(2): 227-242.

Baron, Reuben M., David A. Kenny .1986. "The Moderator-mediator Variable Distinction in Social Pychological Research: Conceptual, Strategic, and Statistical Considerations", Journal of Personality and Social Psychology, 51(6): 1173-1182.

Bentler, P.M., Douglas G. Bonett .1980. "Significance Tests and Goodness of Fit in the Analysis of Covariance Structures", Psychological Bulletin, 88(3): 588-606.

Bhanthumnavin, Duchduen .2000. "Importance of Supervisory Social Support and Its Implications for HRD in Thailand", Psychology and Developing Societies, 12(2): 155-166.

Blau, Peter M. 1964. Exchange and Power in Social Life. New York: John Wiley \& Sons, Inc: USA.

Browne, Michael W., Robert Cudeck .1993. Alternative Ways of Assessing Model fit. K.A. Bollen ve J.S. Long (Eds.), Testing Structural Equation Models içinde (136-162), California: Thousand Oaks, Sage, Newbury Park.

Büyüköztürk, Şener .2012. Sosyal Bilimler İçin Veri Analizi El Kitabı (17. Baskı), Ankara: Pegem Akademi.

Canipe, Jennifer Simone .2006. Relationships Among Trust, Organizational Commitment, Perceived Organizational Support, and Turnover Intentions, Doktora Tezi, San Diego: Alliant International University.

Celep, Cevat, Özge Eler Yilmazturk .2012. "The Relationship Among Organizational Trust, Multidimensional Organizational Commitment and Perceived Organizational Support in Educational Organizations", Procedia-Social and Behavioral Sciences, 46: 5763-5776.

Chen, Chun-Hsi Vivian, Shih-Jon Wang, Wei-Chieh Chang, Chin-Shin Hu .2008. "The Effect of LeaderMember Exchange, Trust, Supervisor Support on Organizational Citizenship Behavior in Nurses", Journal of Nursing Research, 16(4): 321-328.

Costigan, Robert D., Selim S. İlter, J. Jason Berman .1998. "A Multi-dimensional Study of Trust in Organizations”, Journal of Managerial Issues, 10(3): 303-317. 
Taş, A., Özkara, Z. U., Aydıntan, B. / Journal of Yasar University, 2021, 16/61, 147-169

DeConinck, James B .2010. "The Effect of Organizational Justice, Perceived Organizational Support, and Perceived Supervisor Support on Marketing Employees' Level of Trust", Journal of Business Research, 63(12): 1349-1355.

DeConinck, James B., Julie T. Johnson .2009. "The Effects of Perceived Supervisor Support, Perceived Organizational Support, and Organizational Justice on Turnover Among Salespeople", Journal of Personal Selling \& Sales Management, 29(4): 333-350.

Eğriboyun, Dursun .2013. “Ortaöğretim Okullarında Görev Yapan Yönetici ve Öğretmenlerin Örgütsel Güven ve Örgütsel Destek Algıları Arasındaki İlişki”, Kafkas Universitesi Sosyal Bilimler Enstitüsü Dergisi, (12): 17-43

Eisenberger, Robert, Robin Huntington, Steven Hutchison, Debora Sowa .1986. "Perceived Organizational Support", Journal of Applied Psychology, 71: 500-507.

Emhan, Abdurrahim, Sedat Kula, Aykut Töngür .2013. "Yapısal Eşitlik Modeli Kullanılarak Yönetici Desteği, Örgütsel Bağlılık, Örgütsel Performans ve Tükenmişlik Kavramları Arasındaki İlişkilerin Analizi: Kamu Sektöründe Bir Uygulama”, Hacettepe Üniversitesi İktisadi ve İdari Bilimler Fakültesi Dergisi, 31(1): 53-69.

Ergeneli, Azize, Güler Sağlam Arı, Selin Metin .2007. "Psyhological Empowerment and Its Relationship to Trust in Immediate Managers", Journal of Business Research, 60(1): 41- 49.

Frazier, M. Lance, Janaki Gooty, Laura M. Little, Debra L. Nelson .2015. "Employee Attachment: Implications for Supervisor Trustworthiness and Trust", Journal of Business and Psychology, 30(2): 373-386.

Giray, Muazzez Deniz, Deniz N. Şahin .2012. “Algılanan Örgütsel, Yönetici ve Çalışma Arkadaşları Desteği Ölçekleri: Geçerlik ve Güvenirlik çalışması”, Türk Psikoloji Yazıları, 15(30): 1-9.

Gouldner, Alvin W. 1960. "The Norm of Reciprocity: A Preliminary Statement", American Sociological Review, 25: 161-178.

Gürbüz, Rüveyde .2012. Algılanan Örgütsel Destek ve Örgütsel Güvenin, Örgütsel Bağlılık ile İlişkisi, Yüksek Lisans Tezi, Erzurum: Atatürk Üniversitesi, Sosyal Bilimler Enstitüsü.

Hair, Joseph F., William C. Black, Barry J. Babin, Rolph E. Anderson .2010. Multivariate Data Analysis (7. Bask1), New Jersey: Pearson Prentice Hall.

Holland, Peter, Brian Cooper, Cathy Sheehan .2017. "Employee Voice, Supervisor Support, and Engagement: the Mediating Role of Trust", Human Resource Management, 56(6): 915-929.

Hosmer, Larue T. 1995. "Trust: The Connecting Link Between Organizational Theory and Philosphical Ethics", Academy of Management Review, 20(2): 379-403.

Hu, Li-Tze, Peter M. Bentler .1995. Evaluating model fit. R.H. Hoyle (Ed.), Structural Equation Modeling: Concepts, Issue, and Applications içinde (ss. 76-99), California: Sage Publications, Newbury Park.

$\mathrm{Hu}$, Li-Tze, Peter M. Bentler .1999. "Cutoff Criteria for Fit Indexes in Covariance Structure Analysis: Conventional Criteria Versus New Alternatives", Structural Equation Modeling: A Multidisciplinary Journal, 6(1): 1-55.

Huff, Lenard, Lane Kelley .2003. "Levels of Organizational Trust in Individualist Versus Collectivist Societies: A Seven Nation Study”, Organization Science, 14(1): 81-90.

Ji, Seonggoo, Ihsan U. Jan 2020. “Antecedents and Consequences of Frontline Employee's Trust-inSupervisor and Trust-in-Coworker”, Sustainability, 12(2): 1-17.

Kalayc1, Şeref .2010. Spss Uygulamalı Çok Değişkenli Istatistik Teknikleri (5. Baskı), Ankara: Asil Yayınevi.

Keskinkılıç Kara, Sultan B., Demet Zafer Güneş, Nazlı Nazar Aydoğan .2015. "Perceived Organizational Support and Organizational Trust in Primary Schools", International Journal of Human Sciences, 12(2): 385-393.

Kestek, Simge B. 2016. Algılanan Örgütsel Destek ile Örgütsel Güven Arasındaki İlişki: Kuşadası'ndaki 5 Yıldızlı Otel İşletmeleri Üzerine Bir Değerlendirme, Yüksek Lisans Tezi, Aydın: Adnan Menderes Üniversitesi, Sosyal Bilimler Enstitüsü.

Kline, Rex B. 2005. Principles and Practice of Structural Equation Modeling (2. Bask1), NY: The Guilford Press.

Ksiazek, Dawid, Paulina Rozenek, Sabina Warmuz .2016. "The Impact of Perceived Organizational Support on Trust: A case study of a state university", World Scientific News, (48): 108-118.

Lewicka, Dagmara, Aldona Glinska-Newes, Donna L. Morrow, Joanna Gorka .2018. "The Effect of Job Characteristics on Employee Loyalty: The Mediation Role of Vertical Trust and Perceived Supervisory Support”, Marketing and Management of Innovations, 2: 168-185.

Lu, Xiaojun .2014. "Ethical Leadership and Organizational Citizenship Behavior: the Mediating Roles of Cognitive and Affective Trust", Social Behavior and Personality, 42(3): 379-390.

McAllister, Daniel J. 1995. "Affect and Cognition- based Trust as Foundations for Interpersonal Cooperations", Academy of Management Journal, 38(1): 24- 59.

Meydan, Cem H., Harun Şeşen .2011. Yapısal Eşitlik Modellemesi: Amos Uygulamaları (1. Baskı). Ankara: Detay Yayıncılık. 
Taş, A., Özkara, Z. U., Aydıntan, B. / Journal of Yasar University, 2021, 16/61, 147-169

Neves, Pedro, Anto'nio Caetano .2006. "Social Exchange Processes in Organizational Change: The Roles of Trust and Control", Journal of Change Management, 6(4): 351-364.

Newman, Alexander, Kohyar Kiazad, Qing Miao, Brian Cooper .2014. "Examining the Cognitive and Affective Trust-based Mechanisms Underlying the Relationship Between Ethical Leadership and Organisational Citizenship: A Case of the Head Leading the Heart?", Journal of Business Ethics, 123(1): 113- 123.

Nienaber, Ann-Marie, Philipp Daniel Romeike, Rosalind Searle, Gerhard Schewe .2015. "A Qualitative MetaAnalysis of Trust in Supervisor-subordinate Relationships", Journal of Managerial Psychology, 30(5): 507-534.

Özen İşbaşı, Janset .2000. Çalışanların Yöneticilerine Duydukları Güvenin ve Örgütsel Adalete İlişkin Algılamalarının Örgütsel Vatandaşlık Davranışının Oluşumundaki Rolü: Bir Turizm Örgütünde Uygulama, Yüksek Lisans Tezi, Antalya: Akdeniz Üniversitesi, Sosyal Bilimler Enstitüsü.

Özkara, Zülfi U. 2019. Örgütlerde Otantik Liderlik ve Politik Yeti: Hemşireler Üzerinde Bir Araştırma (1. Bask1), Ankara: Gazi Kitabevi.

Özkara, Zülfi U., Güler Sağlam Ar1 .2019. Örgütlerde Güven ve Liderlik: Kavramlar-KuramlarModeller ve Uygulama (1. Bask1), Ankara: Gazi Kitabevi.

Paille, Pascal, Laurent Bourdeau, Isabelle Galois .2010. "Support, Trust, Satisfaction, Intent to Leave and Citizenship at Organizational Level: A Social Exchange Approach", International Journal of Organizational Analysis, 18(1): 41-58.

Preacher, Kristopher J., Geoffrey J. Leonardelli .2010. Calculation For the Sobel Test: An Interactive Calculation Tool for Mediation Tests, http://www.quantpsy.org/sobel/sobel.htm, 11.07.2020.

Rahmani, Saghar, Marzieh Heydari .2017. "Investigating of Trust and Perceived Organizational Support Effects on Organizational Commitment in Educational Organizations, Using Structural Equation Modeling and Partial Least Squares Model”, International Review of Management and Marketing, 7(2): 384-389.

Rosen, Robert H. 1998. Insan Yönetimi. (Çeviren: Gündüz Bulut), İstanbul: Mess Yayınları.

Rousseau, Denise M., Sim B. Sitkin, Ronald S. Burt, Colin Camerer .1998. "Not so Different After at All: A Cross-discipline View of Trust", Academy of Management Review, 23(3): 393-404.

Sağlam Arı, Güler .2003a. "Yöneticiye Duyulan Güven Örgütsel Bağlılı̆̆1 Artırır Mı?”, Gazi Üniversitesi Ticaret ve Turizm Eğitim Fakültesi Dergisi, 2: 17- 36.

Sağlam Arı, Güler .2003b. İşletmelerde Güven ve Personel Güçlendirme İlişkisi: Bankacılık Sektöründe Bir Araştırma, Doktora Tezi, Ankara: Hacettepe Üniversitesi, Sosyal Bilimler Enstitüsü.

Sağlam Arı, Güler, Ayça Tunçay .2010. "Yöneticiye Duyulan Güven ve Tükenmişlik Arasındaki İlişkiler: Ankara'daki Devlet Hastanelerinde Çalışan İdari Personel Üzerinde Bir Araştırma", Atatürk Üniversitesi İktisadi ve İdari Bilimler Dergisi, 24(4): 113-135.

Sarıkaya, Şeref .2019. Öğretmenlerin İş Doyumunun Yordayıcısı Olarak Örgütsel Güven ve Örgütsel Destek Algıs1, Yüksek Lisans Tezi, İstanbul: Marmara Üniversitesi ve İstanbul Sabahattin Zaim Üniversitesi Eğitim Yönetimi ve Denetimi Ortak Yüksek Lisans Programı.

Schaubroeck, John, Simon S. K. Lam ve Ann Chunyan Peng .2011. "Cognition-Based and Affect-Based Trust as Mediators of Leader Behavior Influences on Team Performance”, Journal of Applied Psychology, 96(4): 863- 871.

Settoon, Randall P., Nathan Bennett, Robert C. Liden .1996. "Social Exchange in Organizations: Perceived Organizational Support, Leader-member Exchange, and Employee Reciprocity”, Journal of Applied Psychology, 81(3): 219-227.

Sezgin, Oytun B. 2015. Algılanan Örgütsel Destek İle İçgirişimci Davranışı İlişkisinde Örgütsel Güvenin Rolü, Doktora Tezi, İzmir: Dokuz Eylül Üniversitesi, Sosyal Bilimler Enstitüsü.

Singh, Bushra S.P., Meenakshi Malhotra .2015. "The Mediating Role of Trust in the Relationship Between Perceived Organizational Support and Silence", International Journal of Scientific and Research Publications, 5(9): 1-10.

Stinglhamber, Florence, David De Cremer, Liesbeth Mercken .2006. "Perceived Support as a Mediator of the Relationship Between Justice and Trust: a Multiple Foci Approach", Group \& Organization Management, 31(4): 442-468.

Tabachnick, Barbara G., Linda S. Fidell .2013. Using Multivariate Statistics (6. Bask1), Boston: Allyn \& Bacon.

Tan, Hwee Hoon, Christy S. F. Tan .2000. "Toward the Differentiation of Trust in Supervisor and Trust in Organization", Genetic, Social, and Psychology Monographs, 126(2): 241-260.

Tangi, Münevver E. 2019. Hemşirelerin Ögütsel Güven Düzeyinin Örgütsel Çekicilik ve Algılanan Örgütsel Destek ile İlişkisinin Değerlendirilmesi, Yüksek Lisans Tezi, İstanbul: Haliç Üniversitesi, Lisansüstü Eğitim Enstitüsü.

Taş, Aynur, Zülfi U. Özkara .2020. “İş Stresinin Algılanan Yönetici Desteği ile İşten Ayrılma Niyeti Arasındaki İlişkide Üstlendiği Rol”, OPUS-Uluslararası Toplum Araştırmaları Dergisi, 15(21): 475-504. 
Taş, Aynur, Zülfi U. Özkara, Belgin Aydıntan .2019. Algılanan Yönetici Desteği ve Yöneticiye Duyulan Güven Arasındaki İlişkiler: Üniversite Çalışanları Üzerinde Ampirik Bir Araştırma, 7. Örgütsel Davranış Kongresi, Mehmet Akif Ersoy Üniversitesi, Burdur, 510-519.

Taş, Aynur, Zülfi U. Özkara. 2018. Algılanan Yönetici Desteği ile İşten Ayrılma Niyeti Arasındaki İlişkide İş Stresinin Aracılık Rolü, 6. Örgütsel Davranış Kongresi, Süleyman Demirel Üniversitesi, Isparta, 510 519

Tunçay, Ayça .2009. Güven ve Tükenmişlik İlişkisi: Ankara'daki Hastanelerde Bir Uygulama, Yüksek Lisans Tezi, Ankara: Gazi Üniversitesi Sosyal Bilimler Enstitüsü.

Uysal, Duygu .2019. Yapıcı Sapkın İş Yeri Davranışlarının Örgütsel Güven, Algılanan Örgütsel Destek ve Öz Yeterlik Açısından İncelenmesi, Yüksek Lisans Tezi, Çankırı: Çankırı Karatekin Üniversitesi, Sosyal Bilimler Enstitüsü.

Whitener, Ellen M., Susan E. Brodt, M. Audrey Korsgaard, Jon M. Werner .1998. "Managers as Initiators of Trust: Exchange Relations Framework for Understanding Managerial Trustworthy Behavior”, Academy of Management Review, 23(3), 513-530.

Wong, Carol A., Greta G. Cummings .2009. "The Influence of Authentic Leadership Behaviors on Trust and Work Outcomes of Health Care Staff”, Journal of Leadership Studies, 3(2): 6-23.

Yakut Özek, Bahar .2016. İlköğretim Okulu Öğretmenlerinin Algıladıkları Örgütsel Destek İle Örgütsel Güven Düzeyleri Arasındaki İlişkinin İncelenmesi, Yüksek Lisans Tezi, Ankara: Gazi Üniversitesi Eğitim Bilimleri Enstitüsü.

Yılmaz, Derya .2014. Dağıtılmış Liderliğin Örgütsel Güven ile Algılanan Örgütsel Destek ve Okul Başarısıyla İlişkisi , Doktora Tezi, Eskişehir: Eskiş̧ehir Osmangazi Üniversitesi, Eğitim Bilimleri Enstitüsü.

Yoon, Jeongkoo, Jun-Cheol Lim .1999. "Organizational Support in the Workplace: The Case of Korean Hospital Employees", Human Relations, 52(7): 923-945.

Zhu, Yue, Syed Akhtar .2014b. "The Mediating Effects of Cognition-Based Trust and Affect-Based Trust in Transformational Leadership's Dual Processes: Evidence from China", The International Journal of Human Resource Management, 25(20): 2755- 2771.

Zhu, Yue, Syed Akhtar .2014a. "How Transformational Leadership Influences Follower Helping Behavior: The Role of Trust and Prosocial Motivation", Journal of Organizational Behivor, 35: 373-392. 